\title{
Çokkültürcü Sosyal Hizmet Uygulaması ve Eklektik Perspektif *
}

\section{Multiculturalist Social Work Practice and Eclectic Perspective}

\author{
Fikri Keleşoğlu ${ }^{\mathrm{a}, * *}$, Recep Yıldız ${ }^{\mathrm{b}}$ \\ ${ }^{a}$ Dr. Öğr. Üyesi, Bandırma Onyedi Eylül Üniversitesi, Sağlık Bilimler Fakültesi, Sosyal Hizmet Bölümü, Bandırma 10200, Balıkesir/Türkiye. \\ ORCID: 0000-0002-3736-0179
}

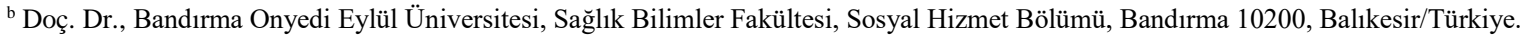
ORCID: 0000-0003-0584-6649

\begin{tabular}{l} 
MAKALE BİLGİSİ \\
\hline Makale Geçmişi: \\
Başvuru tarihi: 01 Kasım 2020 \\
Düzeltme tarihi: 04 Ocak 2021 \\
Kabul tarihi: 11 Ocak 2021 \\
\hline Anahtar Kelimeler: \\
Kuramsal Bakış \\
Mesleki Müdahale \\
Farklılık \\
Çokkültürcü Sosyal Hizmet \\
Eklektisizm
\end{tabular}

ÖZ

Çalışmada sosyal hizmet mesleğine katkı sunan kuramsal çerçeveler çokkültürcülük perspektifinden ele alınmış olup araştırmacılar tarafından oluşturulan tematik başlıklarda tartışılmıştır. Kültürel çeşitliliğin ve farklılıkların beraber yaşandığ 1 toplumlardaki çokkültürcü sosyal hizmet uygulamalarında sosyal çalışmacıya eklektik temelli teorik bir bakış kazandırabilmek amaçlanmıştır. Çalışmada yöntem olarak literatür taraması kullanılmıştır. Çalışma kapsamına alınan kuramsal çerçeveler, sıralanarak tek tek anlatılmamış, ilgili temalara uygun olarak tasnif edilip tartış1larak kuramsal bir bakış verilmeye çalışılmıştır. Çokkültürcü sosyal hizmetin uygulama boyutuna dair sunulan eklektik perspektif ve buradan hareketle geliştirilen öneriler, sonuç bölümünde verilmiştir.

\section{A R TICLE INFO}

\section{A B S T R A C T}

Article history:

Received 01 November 2020

In the study, theoretical frameworks that contribute to the social work profession were discussed from the perspective of multiculturalism and discussed in thematic titles created by the researchers. It was aimed to give the social worker an eclectic-based theoretical perspective in multiculturalist social work practices in societies where there is cultural diversity and differences. Literature review was used as a method in the study. The theoretical frameworks in the study are not explained one by one in order. It has been tried to give a theoretical perspective by classifying and discussing in accordance with the relevant themes. The eclectic perspective and suggestions developed for

Keywords:

Theoretical Perspective

Professional Intervention multicultural social work practice are given in the conclusion section.

Difference

Multiculturalist Social Work

Eclecticism

\section{Giriș}

Sosyal hizmet, özünde farklılığı bir zenginlik olarak gören ve ona göre hizmetlerini çeşitlendiren bir meslektir. Müracaatçılar içinde farklı kesimlerden insanlar ve değişik sosyal öyküler sürekli olagelmiştir (Özbesler ve Bulut, 2013: 101). Bu farklı sosyal öykülerin, farklı yaklaşım biçimleriyle birlikte düşünülmesi ve farklı modellerle ele alınması bir gereklilik olmuştur. Bu gerekliliğin de bir yansıması olarak birçok farklı uygulama çerçeveleri geliştirilmiştir ki bu çerçevelerin odak noktaları değişmektedir. Kimisi bireysel değişiklikleri odağı haline getirirken, kimisi aile, örgüt veya topluluklardaki işleyiş değişikliklerine odaklanır (Sheafor ve

\footnotetext{
* Bu çalışma birinci yazarın 2019 yılında Doç. Dr. Recep YILDIZ danışmanlığında Yalova Üniversitesi Sosyal Bilimler Enstitüsü Sosyal Hizmet Anabilim Dalı'nda yürüttüğü “Sosyal Hizmet Teori ve Uygulamalarında Çokkültürcülük” başlıklı doktora tezinden türetilmiştir.

** Sorumlu yazar/Corresponding author
}

e-posta: fkelesoglu@bandirma.edu.tr 
Horejsi, 2015: 105). Değişen odak noktaları sosyal hizmet mesleğinin icrasında kuramsal bakış açılarını ve buradan hareketle temel dinamikleri oluşturmuştur. $\mathrm{Bu}$ dinamikler üzerinden müracaatçıya dönük yürütülecek her türlü hizmet, mesleğin uygulama çerçeveleri açısından çeşitliliği, kuramsal yelpaze açısından da nitelikli birlikteliği sağlayacaktır.

Sosyal çalışma kapsamında yürütülecek her türlü hizmet bir süreç olarak kabul edilmelidir. Sosyal çalışmayı anlamanın yolu da uygulayıcı ile hizmet alan arasındaki bu süreci bir bağlantı dizesi olarak görmeye bağlıdır (Payne, 2015: 201). $\mathrm{Bu}$ bağlantılar dizesinden oluşan ilişki süreci, kimi zaman sosyal çalışmacıların kişisel ve yerleşik düşüncelerinden etkilenirken kimi zaman da meslek tarafından geliștirilmiş değerlerden ve kuramsal çerçevelerden etkilenir. Burada kritik olan kuramsal bir bakışa sahip olmayan bir sosyal çalışmacının müracaatçısına zarar verebileceği gerçeğidir (Teater, 2014: 9). Bu gerçeğin göz ardı edildiği mesleki ilişkilerde meslek adına bir birliktelikten veya ortak müdahale hizmetlerinden bahsetmek güçtür. Her sosyal çalışmacının kendi tasarruflarına açık olan ve belli bir çerçeveden yoksun mesleki ilişki, müracaatçısına faydalı olmaktan çok onu farklı yönlere çeken, amacından uzak bir mesleki müdahale sürecine götürür.

Sosyal çalışma gibi uygulamalı mesleklerde uygulama ve teoriyi birbirinden ayırmak zordur. Kavram, eylemi her zaman etkiler. Uygulamada temelde "spesifik bir değişiklik yaratmak için bilgiyi kullanma ve teoriyi uygulama sürecidir" (Sheafor ve Horejsi, 2015: 68). Tomanbay'ın (1999: 41) ifadesiyle bilimsel algılamaları kolaylaştıran hatta bir tını oluşmasını sağlayan kavram duyarlılığıdır.

Uygulama adına kavramsal duyarlılık ise kuramsal bir bakış açısına sahip olmaktır. Bu bakış açısından yoksun bir sosyal çalışmacının uygulama adına duyarlılığa sahip olmasının, bilgiyi kullanabilmesinin ve değişiklik oluşturabilmesinin zorluğu öngörülebilir. Özellikle kültürel çeşitliliğin ve farklılıkların olduğu toplumlarda uygulama adına çeşitlilik, bireysel tasarruflardan ve kişisel tercihlerden ziyade, yapılandırılmış kuramsal çerçeveler ve modeller üzerinden sağlanırsa, uygulamanın bütünlüğü açısından da sağlıklı olacaktır. Aksi halde uygulama bütünlüğünden bahsedilemeyeceği gibi yürütülen sürece de bilimsel denemez.

Uygulamaya dair çerçeveler, Sheafor ve Horejsi (2015: 6970) tarafindan uygulama perspektifi, uygulama teorisi ve uygulama modeli olarak üçlü şekilde tasnif edilmiştir. Bu tasnife göre;

$\checkmark$ Uygulama perspektifleri, "kavramsal bir lenstir. Uygulama durumunda neyin değerlendirilmesinin önemli olabileceğine dair belirli bir özellik üzerine yoğunlaşmaya ya da onu büyütmeye hizmet eder."

$\checkmark$ Uygulama teorileri, "hem belirli davranış ya da durumların açıklanmasına hem de bunların nasıl değiştirileceğine dair rehberlik sunar. Uygulama teorisi belirli şekillerdeki değişimleri sağlamak için harita olarak hizmet verir."

$\checkmark$ Uygulama modelleri ise "müdahale eylemine rehberlik etmekte kullanılan kavramlar ve prensipler bütünüdür."

Kuramsal çerçevelerden ve teorik yaklaşımlardan istenilen veya ihtiyaç duyulan bütün cevapları beklemek doğru bir yaklaşım olmayacaktır; ancak teorik bir bakış açısı, ihtiyaç duyulan bir beceridir (Thompson, 2016: 99). Sosyal çalışmacının bu bağlamda kendi mesleki uygulamalarında başvuracağ1, kendisine rehberlik edecek kuramsal çerçeveleri bilmesi, bunlar içinden eklektik bir yaklaşım geliştirerek müracaatçısına hizmet sunması, kendini gerçekleştirmesine firsat vermesi, özellikle kültürel çeşitliliğin olduğu toplumlarda çokkültürcü sosyal hizmet anlayışı adına bir gerekliliktir.

Çalışmada sosyal hizmet mesleğine katkı sunan kuramsal çerçeveler çokkültürcülük perspektifinden ele alınmış olup araştırmacılar tarafından oluşturulan tematik başlıklarda tartışılmıştır. Böylece kültürel çeşitliliğin ve farklılıkların beraber yaşandığı toplumlarda çokkültürcü sosyal hizmet uygulamalarında, sosyal çalışmacıya eklektik temelli teorik bir bakış kazandırabilmek amaçlanmıştır. Bu perspektiften daha önce yapılmış bir çalışmanın olmaması ve sosyal çalışmacılara mesleki müdahale sürecinde tematik olarak pratize edilmiş kuramsal bakışın eklektik olarak sunulması sosyal hizmet literatürü açısından önem arz etmektedir.

Çalışmada yöntem olarak literatür taraması kullanılmıştır. Sosyal hizmetin kuramsal literatürü bu çalışma özelinde taranarak ele alınmıştır. Çalışma kapsamına alınan kuramsal çerçeveler, sıralanarak tek tek anlatılmamış, ilgili temalara uygun olarak tasnif edilip tartışılarak kuramsal bir bakış verilmeye çalışılmıştır.

Uygulamaya dair kuramsal çerçeveler tematik başlıklarda şu şekilde yer almaktadır:

Tablo 1. Uygulamaya Dair Kuramsal Çerçevelerde Tematik Başlıklar

\begin{tabular}{|c|c|}
\hline Holistik Bakış & $\begin{array}{l}\text { Genelci Yaklaşım, Sistem Kuramı, } \\
\text { Güçlendirme Yaklaşımı }\end{array}$ \\
\hline Uyum & $\begin{array}{l}\text { Ekolojik Sistem Yaklaşımı, Sistem } \\
\text { Kuramı, Problem Cözme Yaklaşımı }\end{array}$ \\
\hline Terapötik İlişki & $\begin{array}{l}\text { Psiko-dinamik Kuram, Varoluşçu Kuram, } \\
\text { Güçler Perspektifi }\end{array}$ \\
\hline Kültürel Güç & $\begin{array}{l}\text { Ekolojik Perspektif, Etnik Duyarlılık } \\
\text { Modeli, Güçlendirme Yaklaşımı, Problem } \\
\text { Cözme Yaklassımı }\end{array}$ \\
\hline Ayrım Karşıtlığg & $\begin{array}{l}\text { Etnik Duyarlılık Modeli, Problem Çözme } \\
\text { Yaklaşımı, Feminist Kuram, Radikal } \\
\text { Sosyal Hizmet }\end{array}$ \\
\hline $\begin{array}{l}\text { Bilişsel Cimrilik } \\
\text { Eklektisizm }\end{array}$ & $\begin{array}{l}\text { Etnik Duyarlılık Modeli, Sosyal İnşaacı } \\
\text { Model, Feminist Kuram }\end{array}$ \\
\hline
\end{tabular}

Buradan hareketle "Kültürel farklılıklar görmezden gelinemez. 21. yy. dünyasında, uygulamaya dair çeşitliliğin bilimsel bir birliktelik içinde sunulabilmesinin önkoşulu kuramsal çeşitlilikle beslenen eklektik anlayıştır. Bu da sosyal çalışmacıların mesleki rolünün ve müracaatçıların biricikliğinin gereğidir" ifadesi araștırmanın hipotezi olarak belirlenmiştir.

\section{Holistik Bakış}

Çokkültürcü anlayış ve perspektif bir anlamda holistik bakışın kendisidir. Kuramsal çerçevelerden bu anlayışa farklı katkılar olmuştur. Özellikle genelci yaklaşıma bakıldığında farklı değerler sistemini içine alan birçok mesleki beceriyi kendisinde toplayan bütüncül bir bilgi temeli vardır (Yıldırım ve Yıldırım, 2008: 46-47). Bu bütüncül bilgi temeli, kültürel çeşitliliğin olduğu 
toplumlarda uygulamaya dair becerileri daha sürdürülebilir kılmaktadır. Yine genelci perspektif sosyal çalışmacıya çeşitli seviyelerde müdahale etme imkânı verirken birçok uygulama rolünü de beraberinde kendisine yükler (Sheafor ve Horejsi, 2015: 70). Bu roller içinde sosyal çalışmacı mesleğini icra eder ve çokkültürcü bakışı kazanır. Çokkültürcü bakışla sunulacak tüm hizmetler, müracaatçıya bakan yönüyle aidiyet hissettirecek hizmetlerin önünü açacaktır. Böylece sosyal çalışmacı sunduğu hizmetlerde müracaatçının öznelliği içinde bütüncül bir hizmet sunma şansı olacaktır. Farklılıkları gözetmekle yetinmeyen ayrıca güçlendiren çokkültürcü anlayış günümüz uygulamaları içinde artık bir ihtiyacın karşılı̆̆ıdır (Özgür, 2010: 93). Genelci anlayış insani sorunlar, yaşamsal durumlar ve sosyal şartlar arasındaki ilişkiye vurgu yapan çok boyutlu bir yönelimdir (Sheafor ve Horejsi, 2015: 110). Genelci yaklaşımın vurguladığı bu çok boyutlu ilişki, çoğulcu anlayışla sunulacak sosyal hizmetleri müracaatçının bağlamında ele alır.

Sosyal hizmet her kesimden müracaatçısı olan ve farklılıkları beraber göğüsleyen bir meslektir. Farklılıklara eklektik bilgi temeli ile yaklaşan sosyal hizmet disiplininde genel sistemler teorisi ve ekolojik perspektif ön plana çıkar (Özbesler ve Bulut, 2013: 101).

Sistem kuramının sosyal hizmet uygulamasında geniş bir rolü vardır. Sosyal çalışmacıya bireysel ve toplumsal sorunları birlikte değerlendirebilme konusunda teorik bir arka plan sağlar (Yıldırım ve Yıldırım, 2008: 25). Bu teorik arka plan ile sosyal çalışmacı, müracaatçının içinde bulunduğu yapıyı daha rahat analiz etme ve çözümleme imkânı bulur.

Sistem, sadece parçaların birleşimi değildir. İlişkileri olan ve birbirini etkilemekte olan parçaların oluşturduğu bir bütündür. Çokkültürlü toplumların yaşamını etkileyen birçok temel dinamik ve sistemler mevcuttur. Sistem kuramı bu noktada teorik bir katkı sunarak sosyal çalışmacının sistemler hakkındaki bakışını etkiler, daha geniş holistik bir bakış ile bütün-parça ve diğer sistemler ile olan ilişkileri görmesini sağlar. Nereye odaklanacağına dair sosyal çalışmacıya daha pratik bir bakış ve bilgi temeli sunar (Teater, 2014: 32). Örneğin; çocuk refah alanında çalışan bir sosyal çalışmacı, çocukla ilgili bir soruna müdahale ederken gerek kültürel çeşitliliğin getirdiği yapıyı analiz etmesi, gerekse de sorunla ilgili tüm sistemleri değerlendirmesi sorun çözümünde gerekli olan ilk adımlardandır. Çocuğun sorununa yönelik müdahale planı oluştururken ise bireyle, aileyle, toplum ve kurumla hangisi üzerinden hizmet müdahalesini şekillendireceğini net olarak ortaya koyması ve bütüncül bir anlayış ile toplumun yerel gerçekliklerini dikkate alarak adım atması sorunun daha hızlı ve daha etkili çözümünü beraberinde getirir.

Çokkültürcülük tartışmalarında "farklılıklar" her zaman öne çıkan kavram olagelmiştir. Bu kavramın özünde, temelini bireysellikten alan bir dinamik yapı mevcuttur. Müracaatçısının bireyselliğini onun biricikliği ile birlikte değerlendiren sosyal hizmet mesleği, uygulama çerçevelerinde onun bu yönünü farklı olarak ele alır.

Uygulama çerçevelerinden güçlendirme yaklaşımı, müracaatçısını uzman olarak görür ve fikirlerinden istifade ederek sürece ve çözüme onun bulunduğu yerden bakar, onu kendi yaşam koşullarını en iyi bilen olarak tarif ettiği için süreçte de onu etkin kılar. Müdahalenin her aşamasında kullanılabileceği gibi farklı toplumlardan ve kültürlerden gelen bütün müracaatçılarla da kullanılabilir (Sheafor ve Horejsi, 2015: 115). Böylece müracaatçısını ve onun fikirlerini holistik bakışın odağına yerleştiren, bu odak noktasından hareketle farklılıkları ele alan ve sorunlara bu perspektiften çözüm üreten sosyal çalışmacılar, müdahale sürecinde daha etkin ve faydalı olabilirler. Sosyal hizmet mesleğinin bir amacı da toplumsal bütünleşmeye hizmet etmektir ki; farklılıkların bireysel dinamikler olarak görüldüğü ve buradan hareketle müracaatçısının sorunlarına birlikte çözüm üretildiği güçlendirme anlayışı makro düzeyde toplumsal bütünleşmeye de hizmet edecektir.

\section{Uyum}

Çeşitlilik ve farklılıklar, beraberinde bireyin hayatının merkezine uyum süreçlerini dâhil eder. Özellikle çokkültürlü toplumların en temel problemlerinden biri de uyum sorunları veya uyum süreçlerinin uzun bir dönem olarak kişinin hayatında yer almasıdır. Uyumsuzluk veya kişilerin yaşadıkları uyum problemleri kişi için bireysel bir problem olmaktan öte, sosyal bir problem olarak toplumların ve devletlerin karşısındadır. Çözüm üretilemediğinde ise yine problemin doğuşunda olduğu gibi sonucunda da toplumun genelini etkileyebilecek sosyal bir sorun olarak devam edebilmektedir. Çalışma alanı itibariyle sosyal sorunlara da eğilen sosyal hizmet mesleği ve disiplini bu noktada, kuramsal bilgi temeli ile alana 1ş1k tutmaya, belli bir çerçeve sunmaya çalışmaktadır.

Sosyal hizmet disiplininin kuramsal çerçevelerinden olan ekolojik sistem yaklaşımının ürettiği temel kavramlardan biri de uyum kavramıdır. İnsan organizmasının, çevresi ile uyum içinde olması ve bunu sürdürebilmesi yaklaşımın en temel esasıdır. Müracaatçının yaşadığı uyumsuzluğun ortadan kaldırılabilmesi için ise öncelikle davranışlarının, çevre sistemlerinin ve sorunun tanımlanmasına ihtiyaç vardır (Turan, 2012: 318). Bu tanımlar, kültürel çeşitliliğin olduğu toplumlarda çalışan bir sosyal çalışmacı için esas noktalardır. Sorunun çözümü ve uyum süreçlerine katkı sunabilmek adına mesleki uygulamalarda ekolojik yaklaşıma başvurmak için belli nedenler vardır: İnsan davranışlarının oluşumu ve temel dinamiklerini anlayabilmek, yorumlayabilmek; bireyin çevresindeki aile, örgüt, toplum, organizasyon vb. sistemlerin birbirlerine etkisini görebilmek; danışanın adaptasyon sürecinde etkin rol alabilmesi, inisiyatif kullanilabilmesi bu nedenler arasındadır (Danış, 2006: 53).

Ekolojik yaklaşımı kullanacak bir sosyal çalışmacı, birey ile çevrenin uyumunu öncelikle değerlendirmeli ve ikisini de birbirine uyumlu hale getirecek şekilde müdahalesini planlamalıdır (Teater, 2014: 37). Bireyin çevresi, kültürel ve sosyal çevre olmak üzere iki düzeyde değerlendirilmelidir. $\mathrm{Bu}$ düzeylerden değerler ve normlar kültürel çevreyi oluştururken, insan ilişkileri sosyal çevreyi oluşturur (Danış, 2006: 52). Farklılıkları ve çeşitliliği, diğer bir ifade ile çokkültürlülüğü anlamayı kolaylaştıran ekolojik sistemler, uyum sorunlarını anlamayı ve çözüm üretmeyi de kolaylaştıracaktır. Çalıştığı bölgedeki veya yereldeki toplumsal değerleri, normları, insan ilişkilerini tanımayan ve bunlara uzak olan bir sosyal çalışmacının uyum sorunlarını çözmesi, bunlara çözüm üretmesi, müracaatçı adına sosyal fayda sunması beklenemez. 
Çokkültürlü yapıların analizinde ve etkileşiminde sosyal çalışmacı sistem kuramından ve bu bilgi temelinden faydalanır. Yapı içindeki unsurların bir araya geliş şekilleri, müracaatçı gruplarının istekleri, unsurların süreç açısından nasıl ilişkilendirildiği bu kuramın odağında yer alan noktalardır. (Payne, 2015: 213). Yapıların sosyal çalışmacı tarafindan bu şekilde analiz edilmesi, çokkültürlü toplumlarda yürütülecek hizmetlerin hedefine daha rahat ulaşması ve uyum problemlerinin önüne geçilmesi adına müdahale süreçlerine yön verecektir

Problem çözme yaklaşımı sistem yaklaşımı gibi müracaatçının yaşadığı problemin kaynağını, sosyal ve çevresel sistemlerle birey arasındaki negatif ilişkilere ve olumsuz etkileşimlere bağlamaktadır. $\mathrm{Bu}$ süreçlerdeki bireyin gerçekçi olmayan rol beklentileri, bireyi ruhsal süreçlere göre çok daha fazla etkilemekte ve problemin kaynağını oluşturmaktadır (Danış ve Kara, 2016: 9). Uyum probleminin kaynağını bu yaklaşım perspektifinden ele alan bir sosyal çalışmacının, sistemleri, ilişkileri ve buradan doğan rol beklentilerini görmesi, müdahale sürecini ona göre yapılandırması mesleki müdahalenin sistematik yönünü gösteririr ki, çokkültürcü sosyal hizmetin gereği de budur. Egemen kültürün hissedildiği toplumlarda yaşayan diğer kültür mensuplarının yaşadıkları uyum vb. birçok problem, kuramsal çerçevelerle desteklenerek teorik zemini güçlendirilmiş çokkültürcü mesleki müdahalelerle daha rahat fark edilebilir ve çözümlenebilir.

\section{Terapötik İlişki}

Analitik Hiyerarşi Prosesi, alınması gereken kararlarda sosyal hizmet mesleğinin esaslarından biri olan müracaatçı ile sosyal çalışmacı arasında yürütülen mesleki ilişki sürecidir. Bu ilişki süreci farklı anlayışlardan ve kuramsal perspektiflerden esinlenerek temellendirilebilir. Çokkültürlü bir toplumda yaşayan ve buradaki problemlerine çözüm arayan bir müracaatçı, yardım için bir sosyal çalışmacıya başvurduğunda, aralarında başlayan ilişki sıradan bir ilişki süreci değildir. Mesleki bir ilişki üzerinden temellendirilen ve bazı esaslar üzerine şekillendirilen terapötik bir ilişki sürecidir. Terapötik ilişkinin sürdürülebilir bir mesleki ilişki olması da yine sosyal çalışmacı ile müracaatçı arasında geliştirilen ilişkinin türüne bağlıdır.

Psiko-dinamik kuram, değişim için müracaatçının kendini güvende hissedeceği derinlemesine yürütülen mesleki ilişkiyi gerekli görür. Yine kişinin hisleri ve düşünceleri adına mahrem denebilecek ne varsa bu ilişki ile ortaya çıkarılabilir (Sheafor ve Horejsi, 2015: 123). Kendini güvende hissetmeyen müracaatçının yaşadıklarını, kendi düşüncelerini ve hissettiklerini sosyal çalışmacı ile paylaşmasını beklemek gerçekçi olmayacaktır. Özellikle kültürel farklılıkların ve çeşitliliğin olduğu toplumlarda yaşanabilecek sorunlar da o nispette farklılaşmakta ve çeşitlenmektedir. Çokkültürcü sosyal hizmet anlayışı ile sorun çözümünde güven merkezli mesleki ilişkiyi başlatmak ve süreci bu şekilde yürütmek sağlıklı bir mesleki müdahalenin ilk adımı olacaktır.

Değişim ve sorun çözümü için geliştirilecek olan terapötik iletişimde varoluşçu kuramın temel varsayımları da önemsenmelidir. Özellikle müracaatçının geçmiş ve geleceğine dair düşüncelerinin şimdiye ait yorumlamalarını etkilediği bilinen bir gerçektir (Adams, 2015: 446). Müracaatçının anlam arayışı ve varoluşsal beklentilerine dair kuramın kültürel çıktıları, sosyal çalışmacı tarafindan faydalanılabilecek noktalardır.

Müracaatçı ile terapötik ilişkinin sürdürülmesi, sorunların çözümünü kolaylaştırır. Güçler perspektifine göre, terapötik ilerleme için en sağlıklı yol, müracaatçının hatalarına veya sınırlı yanlarına değil güçlerine odaklanmaktır (Teater, 2014: 49). Her bireyin iyi veya güçlü yanlarını keşfetmek, mesleki ilişki sürecini buna bina etmek sorun çözümünde müracaatçıyı daha da güçlendirecektir. Güçlendirilmiş müracaatçı kendisi ile ilgili olarak daha rahat inisiyatif alacaktır.

\section{Kültürel Güiç}

Çokkültürcü sosyal hizmet, kültürel dinamiklere yüksek farkındalık düzeyi ile bir bakıştır. Kuramsal çerçevelerden ekolojik perspektif tek faktör anlayışını reddederken dört etki alanından bahseder: "Bireyin kendi içinde, kişilerarası ilişkiler yoluyla, toplulukta ve toplumda" farklı etki alanları mevcuttur. $\mathrm{Bu}$ alanlar sosyal çalışmacıya kavramsal bir zemin sunar (Baldwin ve Walker, 2015: 259).

Müracaatçının içinde bulunduğu kültür ve yaşadığı ortam, kendisinin düşünce ve davranışlarını doğrudan etkileyecektir. Etnik duyarlılık modeli buna vurgu yaparak sosyal sosyal çalışmacının kültürel yetkinliğini öne çıkarır. Kültürel yetkinliğe dair beceriler ise öncelikle sosyal çalışmacının öz-farkındalık geliştirmesine bağlı olarak gelişir (Sheafor ve Horejsi, 2015: 115-116). Kendini ve kültürel gerçekliğini tanıyamamış, bu konuda öz-farkındalık geliştirememiş bir sosyal çalışmacının, müracaatçısının kültürel gerçekliğini görmesi ve buna uyumlu bir müdahale süreci planlaması pek mümkün değildir. İnanç, değer, tutum, gelenek vb. birçok toplumsal dinamik müdahale sürecinde düşünülmeli ve bunlarla uyumlu bir hizmet modeli ortaya konmalidır.

Güçlendirme yaklaşımını esas alan bir sosyal çalışmacı ise müracaatçısının kültürel güçlerine dair farkındalığını artırmalı ve bu konuda onunla işbirliği yapmalıdır. Kendi kültürüne özgü güçleri ve kaynakları en iyi bilen yine müracaatçıların bizzat kendisidir (Teater, 2014: 61). Kendisi ve çevresi konusunda farkındalığı yüksek müracaatçılar ile işbirliği temelli bir ilişkinin kurulması kültürel güçleri tanımayı kolaylaştıracağı gibi müracaatçıyı da güçlü k1lacaktır.

Problem çözme yaklaşımında, "sosyal biliş" problemin çözümünde sosyal çalışmacıya farkındalıklar sağlar. Bu şekilde sosyal çalışmacının "toplumsal işaretleri doğru yorumlayabilme" becerisi gelişir (Bacanlı, 2014: 10). Çokkültürcü sosyal hizmet anlayışını referans alan sosyal çalışmacıların sosyal biliş düzeylerinin artırılması, sağlıklı sosyal hizmet müdahalesinin önünü açacaktır. Yine bu yaklaşım doğrultusunda elde edilen beceri, meslek elemanına analitik düşünme becerisi de kazandıracaktır (Attepe Özden ve İçağasığlu Çoban, 2015: 166-167).

Kültürel güç bağlamında kuramsal çerçeveler sosyal hizmet mesleğinin sunumunda özellikle yetkinlik odaklı çalışmaya güç katar. Kültür, müdahale boyutlarında belirleyici bir unsur olarak sosyal hizmet uygulamasına, "özgürleştirici" bir pratik kazandırır; ancak bunun sağlanabilmesi eleştirel yaklaşımın savunduğu düşünümsellik ile mümkündür. Aksi takdirde özgürleştirici ve güçlendirici sosyal hizmetin sunumu zordur (Özgür, 2010: 103). 
Günümüzde küreselleşmenin de etkisi ile kültürler artık birbirlerine oldukça yaklaşmış ve birbirinden etkilenir olmuştur. Toplumların kültürel farklılıkları eğer ki zenginlik olmaktan çok ayrıştırma sebebiyse bu toplumda bireylerin sağlıklı hizmet alması zor olacaktır. Özellikle sosyal çalışmacı, kültürel yetkinliğe sahip biri değilse bu hizmetin sunulması daha da güçleşecektir. Kültürel zekâ da yine küreselleşme sonrası ortaya atılmış kavramlardan biridir. Earley ve Mosakowski'ye (2004: 139) göre kültürel zekâ kişinin karşısındaki kişiyi farklı kültürden de olsa aynı kültürdenmiş gibi anlayıp, yorumlayabilmesidir. Mercan (2016: 3) ise kültürel zekâyı, "çokkültürlü ortamlarda kültürel farklılıkları yönetmek amacıyla iletişim kurma becerisinin yanı sıra karşısındaki farklı kültürel özellikleri benimseme, algilama, yorumlama ve hissetme" olarak tanımlamıştır.

Kültürel zekâ tek boyutlu bir kavram değildir. Dolayısıyla kültürel zekâyı ölçmek için geliştirilmiş olan ölçek de aynı şekilde tek bir boyutu ölçmemektedir. Ang vd. (2007) tarafından geliştirilmiş olan Kültürel Zekâ Ölçeği-KZÖ (Cultural Intelligence Scale-CIS) 20 maddeyle 4 ayrı boyutu ölçmektedir: Üst Biliş, Biliş, Motivasyon, Davranış. İlhan ve Çetin (2014: 94) kültürel zekâ ölçeğinin geçerlik ve güvenirlik çalışması yaparak Türkçe formunu oluşturmuştur. Mercan'ın (2016: 6-10) bu ölçeği kullanarak yapmış olduğu araştırma sonuçları kültürel zekânın kültürlerarası duyarlılığı artırdığı ortaya çıkmıştır. Kültürel zekânın sosyal çalışmacılara bakan yönü, bilişsel zekâdan farklı olup duygusal zekâ gibi geliştirilebilir olmasıdır (Mercan, 2016: 3). Geliştirilebilir olan bu yön, çeşitliliği ile karakterize mesleki uygulamalarda temel aktör olan meslek elemanlarının kültürel duyarlılığının artırılarak güçlendirilmesine kaynaklık edecektir.

\section{Ayrım Karşıtlığı}

İnsan dünyaya geldiği ve ayrıldığı güne kadar geçirdiği dönemde birçok farklılıklar ve ayrılıklar üzerinden hayatı deneyimlemektedir. Bu farklılıklar ve ayrılıklar kimi zaman sorunun kaynağı kimi zaman ise çeşitliliğin güzel bir resmidir. Çokkültürlü olan ancak çokkültürcü olamamış toplumlarda bu farklılıklar bir ayrım sebebi olmuş ve buradan doğan haksızlıklar sürekli olarak toplumsal sorun olarak gündemde kalmıştır. Sosyal hizmet gibi insana dokunan ve kişinin hayatında insan onuruna yaraşır farklılıklar oluşturmaya çalışan meslek grupları, bu sorunsala çözüm üretmek için gerek bilgi gerekse beceri boyutunda gayret göstermiştir. Özellikle bu sahada olan akademik disiplinler bilimsel bilgi üretmenin yollarını aramışlardır.

Uygulamaya dair kuramsal çerçeveler, kültürel çeşitliliğin olduğu toplumlarda müdahale sürecinin daha bilimsel bir temele oturmasına katkı sunar. Ayrım karşıtlı̆̆ı esasında sosyal çalışmacı için temel bir duruştur. Bu noktada özellikle etnik duyarlılık modeli, feminist teori, radikal sosyal hizmet gibi çerçevelerin ön plana çıktığı görülebilir. Diğer yaklaşım ve modellerde ayrım karşıtlığı konusunda sosyal hizmet disiplinine katkı sunmuşlardır.

Eşitsizliklere ve farklılıklara duyarlı olmak sosyal hizmet mesleğinin güçlü bir geleneğini oluşturur (Cree, 2015: 69). Etnik duyarlılık modeli de bu duyarlılıkları ile ön plana çıkar. Özellikle müracaatçıların etnik ve kültürel farklılıkları, sosyo-ekonomik düzeyleri, dini temayülleri, onun davranışlarını belirleyen, düşüncelerini etkileyen unsurlar olarak modelde dikkat çeken noktalardan olmuştur. Bu gibi noktalar üzerinden ayrıştırılan müracaatçıların sorunlarına çözüm üretecek bir sosyal çalışmacı, bu modelden faydalanmak istediğinde model sosyal çalışmacıya, çokkültürcü sosyal hizmet anlayışıyla birlikte birçok perspektif sunar.

Kişinin kendini tanımladığı ve farklı olan yanı onun kendi kimliğidir. Glasser'a (1999) göre herkesin temel sayılabilecek tek ihtiyacı, kimlik ihtiyacıdır. Dünyada farklı olan yanımızı hissetmenin tek yolu da yine insanın kendi kimliğidir (Yıldırım ve Yıldırım, 2008: 200). Problem çözme sürecinde, farklılıkları müracaatçının kimliği üzerinden okumak kabul etmek ve ona uygun çözüm yollarını aramak ve geliştirmek problem çözme yaklaşımının da temelidir. Kişinin ayrımcılık yaşadığı alanların tespiti, bunlar ile yüzleşme, sonrasında ortadan kaldırma ve bu süreçte işbirliği odaklı roller üstlenme sosyal çalışmacı ve müracaatçı arasındaki problem çözme yaklaşımının adımları oluşturur (Teater, 2014: 224).

Çokkültürlü toplumların en dikkat çeken yanlarından biri de baskın kültürlerin diğer kültürler üzerine kurduğu hâkimiyetlerdir. Bu noktada sosyal hizmet literatürüne katk1 sunan diğer bir çerçeve feminist kuramdır. Kuram, özellikle toplumsal cinsiyet rollerinin baskın kültür ile dağıtılmasına itiraz eder ve bununla mücadele eder (Teater, 2014: 106). Özellikle kadını baskı unsurlarının bir parçası olarak değil, onların dışında özerk bir birey olarak ele alır (Öztürk, 2013: 197). Ayrımcılığın bu türlüsünü ve toplumsal cinsiyet üzerinden duyulan endişeleri gidermek adına mücadeleyi gerek kuramsal bilgi temelinde gerekse uygulama boyutunda sürdürür.

Yoksulluk, sınıf vurgusu ve bunun üzerinden ayrıştırılan insanların yaşadıkları toplumsal sorunların çözümü ile ön plana çıkan radikal sosyal hizmet ise ayrımcılık temasında dikkat çeken diğer bir kuramsal çerçevedir. Diğer yaklaşımların bu konulara yeteri kadar eğilmediği ve eksik vurgu yaptığına dair memnuniyetsizlikten doğmuştur (Thompson, 2016: 101). Yoksulluk, işsizlik adına belli kesimlerin daha ayrıcalıklı iken belli kesimlerin daha da yoksullaşmasına itiraz eden, makro planda çözüm arayan bir anlayıştır. Sosyal çalışmacı çoğulcu anlayış içinde bunlarla da mücadele eden bir meslek elemanıdır.

İnsanları tektipleştirme eğilimi esasında yeni değildir ve modernleşme süreci ile birlikte sürekli verilmeye çalışılmıştır. Daha çok benzerliklerin ön plana çıktığı bu akım sonrası gelişen postmodernizm ile artık farklılıklar benzerlik politikalarının yerini almaya başlamıştır. Farklılık söylemleri geliştirilmeye başlanmıştır. Avrupa ve Amerika Birleşik Devletleri'ndeki farklı grupların siyasette arada kalmışlıkları bunun göstergesi olarak kabul edilebilir (Kutlu ve Alsancak, 2018: 296).

Kültürel farklılıkların olduğu toplumlarda hizmet sunan sosyal çalışmacıların, ayrımcılığı teşvik eden nefret suçlarını ve söylemini deneyimlemiş müracaatçılar ile çalışması yüksek ihtimaldir. Tablo 2'de Türkiye'de 2008 y1lından geriye dönük olarak medya üzerinde yapılmış olan 10 yıllık tarama sonuçlarında bunu okumak mümkündür: 
Tablo 2. Nefret Suçları ve Nefret Söylemiyle İlgili Medya Taramasının Sonuçları

\begin{tabular}{|c|c|c|c|c|c|c|}
\hline \multicolumn{7}{|l|}{ Medya Taraması Toplam Verileri } \\
\hline Kategori & \multicolumn{2}{|c|}{ Nefret suçları } & \multicolumn{2}{|c|}{ Nefret söylemi } & \multicolumn{2}{|c|}{ Toplam } \\
\hline & Toplam & $\%$ & Toplam & $\%$ & Toplam & $\%$ \\
\hline Etnik köken & 245 & 23.76 & 1861 & 46.98 & 2106 & 42.18 \\
\hline Din ve inanç & 163 & 15.80 & 829 & 20.92 & 992 & 19.87 \\
\hline Ulusal kimlik & 29 & 2.81 & 524 & 13.2 & 553 & 11.07 \\
\hline Siyasal eğilim & 194 & 18.80 & 211 & 5.32 & 405 & 8.11 \\
\hline Toplumsal statü & 123 & 11.93 & 186 & 4.69 & 309 & 6.18 \\
\hline Cinsel kimlik & 167 & 16.19 & 114 & 2.87 & 281 & 5.62 \\
\hline Cinsel yönelim & 71 & 6.88 & 199 & 5.0 & 270 & 5.40 \\
\hline Bedensel engellilik & 23 & 2.23 & 28 & 0.7 & 51 & 1.02 \\
\hline Mülkiyet & 16 & 1.55 & 5 & 0.12 & 21 & 0.42 \\
\hline Eğitim durumu & 0 & 0 & 4 & 0.10 & 4 & 0.08 \\
\hline Toplam: & 1031 & 100 & 3961 & 100 & 4992 & 100 \\
\hline
\end{tabular}

Kaynak: Alğan ve Şensever (2010: 29) ${ }^{1}$

$\mathrm{Bu}$ veriler bir bakıma ülkede hangi kategorilerde ayrımcılık yapıldığını da göstermektedir. Bu kategorilerin herhangi birinde olumsuz bir deneyim yaşamış müracaatçıly çalışacak sosyal çalışmacının bu perspektiften hareketle seçeceği kuramsal çerçeveler mesleki müdahalenin niteliğini etkileyeceği gibi daha spesifik faydalar da sunacaktır.

Tablo 2'ye göre, Türkiye'de nefret suçu ve söylemlerinde en üst sırada etnik köken gelmektedir. Buradan hareketle toplumun duyarlılık ve hassasiyetinin yoğun olduğu alan ortaya çıkmaktadır. Farklılıklara dair zaafı olanların, farklılıkları kabul etmek yerine onları ötekileştirmek ve sosyal dişlanmalara maruz bırakmak daha çok tercih edilendir. Müracaatçıların kültürel çeşitlilik veya farklılıklarının olduğu herhangi bir alan sebebiyle maruz kalacağı bir ayrımcılıkta, sosyal çalışma mesleğinin mensuplarının, hak savunuculuğu yapması, sorunun kaynağına inmesi, ihtiyaç sahibinin kendi geleceğini tayin edebilecek noktada güçlendirilmesi, kuramsal bilgi temelinin de gereğidir. Bu bilgi temeli çokkültürcü sosyal hizmet uygulamasını da güçlü kılmaktadır. Uygulamaların kuramsal bilgi temeli ne kadar zayıf olursa uygulamaların sürdürülebilir ve savunulabilir olması da o oranda güçleşir. Kanıt temelli uygulamaların sayısı da aynı şekilde azalır.

Ayrımcılık karşıtı uygulamalar, ayrımcılıktan kimlerin ne şekilde etkilendiğini ortaya koymanın yanında sosyal çalışmacının kendisinde mevcut olan bir önyargıyı anlamasını da sağlar. Ayrımcı kavram ve söylemler, günlük hayatta kullanılmaya devam edilip medya ve propaganda ile de işlenerek kültürden kültüre aktarılmaktadır (Cankurtaran ve Beydilli, 2016: 149). Bu söylem ve aktarımlar ise ayrım karşıtı uygulamaları zorlaştırdığı gibi, toplumsal çeşitliliğin ayrıştırıcı farklılıklar olarak referans alınmasına da sebep olmaktadır. Kuramsal çerçevelerden bu perspektiften faydalanılarak uygulama adına bilgi temelinin oluşturulması, çokkültürcü sosyal hizmet uygulamalarını ayrım karşıtlığına yönelik daha da güçlendirecektir

\section{Bilişsel Cimrilik}

Çokkültürlü toplumların en büyük ihtiyacı, esasında bilişsel cimriliğe gösterilecek mesafeli duruştur. Bilişsel cimrilik Hewstone'a (akt.: Demirtaş, 2003: 133) göre "çevremizdeki insanlara ilişkin bilgi yükünü azaltma"dır. Bu da farklı olan her bireyi aynı veya benzer görmekle yine benzer tepkileri göstermek şeklinde sosyal sınıflandırmaları beraberinde getirir. Sosyal hizmet bir anlamda farklılıklara duyarlı olma mesleğidir (Cree, 2015: 69). Etnik duyarlılık modeli farklılıkları gören ve bunun görülmesi ve kabul edilmesi adına mücadele eden bir modeldir. İnsanların farklılıkları, ihtiyaçların farklılığını da beraberinde getirir. Sosyo-kültürel birçok faktör müracaatçının ihtiyaçlarını etkileyen hatta belirleyen noktalar olabilmektedir (Yıldırım ve Yıldırım, 2008: 23). Model, etnisite ve diğer duyarlılık alanları ile çokkültürcü sosyal hizmeti, daha uygulanabilir kılmaktadır.

Sosyal inşacı model ise insanın bilgiyi nasıl bulduğundan ve keşfettiğinden ziyade nasıl ürettiğine odaklanır (Teater, 2014: 89). Bu yönü ile uygulama teorileri arasında kabul edilebilir. Bu modeli benimseyen bir sosyal çalışmacı, her bireyin deneyimine ayrı ayrı önem verir. Müracaatçısının yorumlarında, toplumun ve sosyo-kültürel değerlerin etkisini görmeye ve çözümlemeye çalışır.

Makro sosyal hizmet uygulamalarında feminist vurgunun, kadınların ihtiyaçlarını ve farklılıklarını anlamak adına katkıları olmuştur (Keçeci, 2017: 189). Çokkültürcü anlayış ile bu perspektiften aranan çözüm yolları, toplumsal cinsiyet rollerine dair sosyal çalışmacıyı bilişsel cimrilikten uzak tutar. Kadını anlamak demek, kadına sadece hak vermek veya bilimsel metinler üzerinde hak tartışması yapmak demek değildir. Kadının yaşadığı koşulları her şekliyle anlayabilmeyi daha da ötesinde hayatta üstlendiği rollerin farkında olup bu farkındalık üzerinden anlayış ve sosyal hizmet müdahalesi geliştirmeyi gerektirir. Diğer türlüsü marjinal veya popülist söylemlerden öteye geçmediği gibi, kadına hak ettiği gerçek değeri de vermemektir Böyle bir durum feminist söylemi kendi teorisi ve bilgi temeliyle çelişir duruma getirir.

Bilişsel cimriliğe sebep olan söylemlerden biri de modernist akımdır. Buna, karşı tez olarak ortaya çıkan postmodernizm ise birey ve toplumların farklılıklarını tanımaya sevk ettiği için, bilişsel cimriliğe mesafeli bir duruştur. Şan'a (2006: 75) göre farklılıkların birbiri üzerinde egemen olamayacağını ve eşit temsil yetkisine sahip olduğunu savunan postmodern teori, sonrasında farklılıkların kutsandığı çokkültürcü politikalara meşru zemin oluşturulmuştur. Çoğulculuğun ve farklılıkların bazı kesimlerce eleştirildiği bazı kesimler tarafından ise savunulduğu gerçeği göz ardı edilmemekle birlikte burada esas olan, farklılıklara kutsallık atfetmeden ve bilişsel cimriliğe girmeden sosyal çalışmacının,

${ }^{1} 2008$ yılından geriye doğru 10 yıllık dönemdeki 20 gazetenin internet sitesinden, nefret suçlarına dair tarama yapılmış olup 30 bin örnek incelenmiştir. 
müracaatçısı ile birlikte yürüteceği profesyonel mesleki ilişkiyi sağlıklı ve sürdürülebilir kılmasıdır.

Kültürel değişkenlerden olan "kültürel mahremiyet algısı" üzerinden şekillenen aşağıdaki örnek olgu, yerele dair farklılık ve çeşitlilik bilgisinin önemsenmediği, bilişsel cimriliğin öne çıktığı hizmet anlayışının sahadaki yansımasını somut olarak göstermektedir. Şöyle ki, 2011 Van depreminde tuvalet ve banyo ihtiyaçları için köyün ortasına bırakılan konteynır ve çadırdan köyün sosyal dokusu gereği büyük çoğunluğu rahat bir şekilde faydalanamamış, çekinceli tavır ortaya koymuştur (Yaman ve Akyurt, 2013: 129). Deprem bölgesinde yaşanan bu örnek, kültürel duyarlılığın çokkültürcü hizmetlerdeki yerini net olarak ortaya koymaktadır. Bu perspektiften kuramsal bilgi temelinin güçlendirilmesi mesleki müdahaleleri de uygulanabilir k1lacaktır.

\section{Eklektisizm}

Sosyal çalışmacıların müdahale hizmetlerini planlarken ve bu hizmetleri sunarken kullanabileceği birçok kuramsal çerçeve olduğu daha önceki ilgili başlıklarda vurgulandı. Peki bir sosyal çalışmacı tüm çerçeveleri düşündüğünde kendisine nasıl bir yol haritası çıkaracak?, Bu çerçevelerden hangisini kendisine rehber edinecek?, Hangisi karşılaştığ vaka için ona daha çok katkı sunacak? şeklindeki birçok sorunun cevabı yine sosyal çalışmacının kendisindedir. Mesleki yeterliliği de süreçte kendisine katkı sunacak ve müracaatçısı için hangisinin doğru bir çerçeve olduğuna karar verecektir. Bir doktor düşünün ki, her hastasına tek bir ilaç ve tek bir tedavi yöntemi kullanıyor. Her yaş grubuna aynı metotla tedavisini sürdürüyor. Böyle bir yaklaşımın, yöntemin, tekniğin veya anlayışın hastalarda karşılık bulması mümkün değildir. Bazıları için geçerli olan doğrular, birçok hasta için doğru veya istenen etkiyi sağlamaz. Aynı şekilde sosyal çalışmacı da bir profesyonel olarak mesleğini icra ederken kullanacağı kuramsal çerçeveleri belli kalıplar üzerinden değil, daha çok müracaatçısı üzerinden şekillendirerek yol haritasını belirler. Çokkültürcü sosyal hizmet uygulamalarının, farklılıklar ve çeşitlilikler üzerinden sunulabilmesi ve sürdürülebilmesi böyle bir perspektifi gerekli kılar. Kültürel farklılıkları olan, sosyal gerçeklikleri ve geçmiş yaşantıları apayrı olan gerek bireylerin gerekse toplumların ihtiyaçları ve sosyal öncelikleri her zaman değişecektir. İnsana hizmet, insanın farklılığının kabulüyle başlar. Farklılıkların kabulü de farklı müdahale türlerini ve yaklaşımlarını gerektirir. İşte tam da bu noktada sosyal çalışmacının karşısına kuramsal çerçeveler çıkar. Sosyal çalışmacının karşılaştığı vakanın temel dinamiğini keşfetmesi ve kullanacağ 1 kuramsal çerçeveye, yöntemine ve tekniğine karar vermesi, mesleki müdahalesinde ilk adım niteliği taşır. Farklı çerçevelerin bir arada olması, bazen öncelik sırasına göre yer değiştirmesi, eklektik yaklaşımın doğasının bir gereğidir.

İnsanın birey olarak bütüncül yanı, kuramların da belli açılardan bu bütünlüğe uygun etkileşimlerini lüzumlu kılar (Topses, 2012: 73). Her bir sosyal çalışmacının uygulama yaklaşımlarını ortaya koyarken bu perspektiften yararlanması çokkültürcü sosyal hizmeti, müracaatçı açısından karşılığı olan uygulamalar bütünü haline getirecektir. Thompson'ın (2016: 47) vurguladığı gibi sosyal çalışmacının temel görevlerinden biri müracaatçı için belirsizliği yönetebilmektir. $\mathrm{O}$ halde her müracaatçının yaşantısı da kendisine özel olduğuna göre, bu belirsizlikler yönetilirken eklektik yaklaşımın esas tutulması problemin öznelliğine daha uygundur.

Sosyal hizmet, "bireylerin toplum içinde kendilerini ifade edebilmeleri, yaşam standartlarının iyileştirilmesi ve toplumda sosyal adaletin sağlanmasına yönelik programlardan oluşan bir bütündür” (Eroğlu, 2013: 25). Tanımdaki bu üç dinamik unsur, eklektik yaklaşım içinde sunulacak farklı ekollerle müracaatçı adına daha etkin ve daha hızlı sonuçlar verecektir.

Sosyal hizmet mesleğinin icrasında yardım isteyene yardım götürmek esastır. Yardım süreçlerinde iyi niyetli olmak, yardım sürecini işlevsel kılmak için yetmez. "Zarar vermeme" ilkesi göz önünde bulundurularak yardım süreçlerinde bireylerin hak temelli tüm taleplerine cevap verilir. Mesleki müdahaleler yürütülürken, geleneksel yaklaşımlar yanında güncel yaklaşımlarında dikkate alınarak birbirini beslemesi modern anlayışın gereğidir. Sunulan hizmetlerde mesleki etik ve ilkeler gözetilirken, ideal olan yaklaşım şekli ise vakadan vakaya değişebilmektedir (Acar, 2013: 251). Eklektik yaklaşımın gereği de buradan doğar.

Günümüz modern anlayışı ve sosyal hizmet disiplini farklılıklar üzerine çalışırken eklektik yaklaşımı savunur (Özbesler ve Bulut, 2013: 101). Eklektik yaklaşımdan hareketle müdahale planı oluşturan bir sosyal çalışmacı, müracaatçının yüksek yararını gözetirken kendini vaka özelinde daha zengin hissedecektir ki, bu da kuramsal çerçevelerin zenginliğinden gelmektedir.

Peki, sosyal çalışmacının bu kuramsal çerçevelere çokkültürcü sosyal hizmet yaklaşımında ihtiyacı var mıdır? Varsa ne gibi gerekçelerle vardır? Davranışlar ve durumlar, kültürel çeşitliliğin olduğu toplumlarda sunulacak hizmetlerin planlanmasında ve sürdürülebilir olmasında gerekli referanslardır. Kuramlar tam da bu noktada rol üstlenerek müracaatçının davranışlarını ve durumlarını anlamlandırmayı, açıklamayı ve anlamayı sağlar. Geçmişte olanları ve gelecekte olabilecekleri müracaatçı adına kestirebilmeyi ve bu konuda içgörü kazanmayı kolaylaştırır. Sosyal çalışmacının müracaatçısına yönelik sürdüreceği mesleki ilişkisinde, kuramsal çerçeveleri sosyal hizmetin değerleri ile uyumlu bir şekilde kullanmak gibi bir sorumluluğu da vardır. Bu sorumluluğun gereği olarak sosyal çalışmacı kendi sezgilerine, doğrularına ve varsayımlarına göre hareket edemez (Teater, 2014: 12-13). Buradan hareketle sosyal hizmet disiplinine katkı sunan birçok kuramsal çerçeve bu çalışmada ele alındığı şekliyle birçok temada sosyal çalışmacının karşısına çıkmakta ve farklı vakalarda farklı yaklaşımların sergilenmesini kolaylaştırmaktadır. Her müracaatçının ait olduğu kültür ve yerel dinamikler, onun kendi benliğinin oluşmasında, birey olarak şekillenmesinde etkili olmaktadır. Kültürel farklılıklar toplumda bireysel farklılıkları görünür kılar. Müracaatçıların ait olduğu kültür ve bunun etkisiyle kendisinde oluşan bireysel farklılıklar, onun için anlamlı farklılıklardır. Sosyal çalışmacının bu bireysel farklılıkları vaka sürecinde önemsemesi, hangi kuramsal yaklaşımla çalışacağına dair müracaatçının öznel yanlarını dikkate alması, eklektik yaklaşım ve bütüncül uygulamaların çıktıları arasındadır.

Hiçbir kuram ve yöntem kendisi tek başına bir sorunun çözümünde sosyal çalışmacı için yeterli değildir. Bu sebeple 
sosyal çalışmacı özellikle çokkültürlü toplumlarda hizmet sunumunda eleştirel bakışı bırakmamalıdır. Başarılı bir eleştirel bakış, muhakemenin kuramsal çerçevelerle beslenmesine bağlıdır. Muhakemenin beslenmesi, sosyal çalışmacının vakalarda daha kesin ve daha hızlı yanıtlar vermesini sağlar (Teater, 2014: 12).

Holistik bakış, uyum, terapötik ilişki, kültürel güç, ayrım karşıtlığ1 ve bilişsel cimrilik üzerinden oluşturulmuş tüm bu temalar çokkültürlü toplumlardan etkilenerek şekillenir. Bunun farkında olan bir sosyal çalışmacı, uygulama boyutunda faydalanacağı bilgi temelini ona göre oluşturur ve müracaatçının farklılıklarını çokkültürcü sosyal hizmet ile muhakeme ederek hizmet sunumuna geçer. Bunu gerçekleştirebilirse o zaman müracaatçısını ötekileştirmeyen ve onun öznelliğini önemseyen bir hizmetten bahsedilebilir. Aksi takdirde sadece bir kuramsal çerçeveyi esas alan ve bu şekilde bir bilgi temeli oluşturan sosyal çalışmacının sunduğu hizmet ve uygulama kültürel yetkinlik açısından tartışmalı olur. Eklektisizm ise mesleki yetkinliğe referans olacak çözümleri, çokkültürcü sosyal hizmet üzerinden çeşitlendirir. Her bireyin farklılıklarını farketmek ve kültürel olarak yetkin uygulamalar sunmak adına eklektik yaklaşım tüm kuramsal çerçeveleri önemser ve müracaatçının kendi bireyselliğine ve biricikliğine zarar vermeden bütüncül bir yaklaşım içinde onu kendi sosyal bağlamından koparmadan sosyal çalışmacıya müdahale firsatı sunar. $\mathrm{Bu}$ firsatı değerlendirebilmek ise sosyal çalışmacının kendi muhakemesini ne kadar beslediğiyle ilgili olarak uygulamanın yetkinliğine yansır.

Sosyal hizmet disiplin olarak "sadece birey ve toplum arasında değil, aynı zamanda birçok çatışan güç arasında olması açısından da iki ateş arasındadır" (Thompson, 2016: 24). İki ateş arasında olmak, sosyal çalışmacının çokkültürlü toplumlarda sunacağı hizmetleri yetkin bir şekilde sunabilmesini de gerekli kılar. Müracaatçıların yaşantılarını ona uygun kuramsal çerçevelerle ele almayan bir sosyal çalışmacı eklektik anlayıştan da uzaklaşmaktadır. Bu bağlamda her sosyal çalışmacının çokkültürcü sosyal hizmetin kuramsal bilgi temelinde göstereceği eklektik hassasiyet, uygulama boyutuna da çoğulcu anlayışı kazandırır. Bu da sosyal hizmet uygulamalarının kuramsal bilgi temelini daha işlevsel kılar.

\section{Sonuç}

Sosyal hizmet disiplini içinde uygulama boyutunda kullanılacak kuramsal çerçevelerin çeşitliliği bu disiplinin kuramsal bilgi temeline zenginlik katarken aynı zamanda uygulamada birliktelik, bütünlük ve tutarlılığın sağlanmasına da hizmet etmektedir. Uygulamaya kavram ve prensipler yönüyle bir perspektif sunan kuramsal bakış, sosyal çalışmacıların ihtiyaç duyduğu bir mesleki beceridir. $\mathrm{Bu}$ çerçeveler, uygulamada sosyal çalışmacılara birliktelik sağlamak yanında, vaka yönetiminde kendisine rehberlik de etmektedir. Bununla birlikte literatürde yer alan birçok kuramsal çerçevenin vaka özeline indirgenerek uygulanması sosyal çalışmacılar için her zaman mümkün olamamaktadır. Zaten sosyal çalışmacıların uygulama becerisini artırabilmek adına kuramsal eğitimin yanında farklı teknik arayışları da bunun bir yansımasıdır (Ercan ve Tekgöz Obuz, 2016). Bu gerekçe ile çalışmada kuramsal çerçeveler tek tek işlenmemiş bunun yerine çokkültürlülüğe bakan yönüyle kuramsal çerçeveler tematik başlıklar halinde ilgili bölümlerde tartışılmıştır. Kuramsal çerçevelerin tematik başlıklar halinde tartışılması, çokkültürcü sosyal hizmet uygulamalarında ve vaka yönetim sürecinde sosyal çalışmacıya bilgi temelindeki kuramsal farkındalık katkısı sunmaktadır. Bunun yanında uygulamadaki kuramsal karmaşanın önüne geçilmesi de beklenmektedir.

Çokkültürcü toplumlarda müracaatçıların her birinin farklı kültürlerden gelebilmesi, sorunların çözümünde aynı yöntemin farklı sonuçlar doğurabilmesi, uygulamada kültürel boyutun yansımalarını görebilmeyi gerekli kılmıştır. Uygulamalı bir bilim olarak sosyal hizmetin teorik çerçevesinin bu bağlamda kritik edilmesi, uygulamaya kültürel duyarlılık kazandırılması adına gerek müracaatçılar gerekse sosyal çalışmacılar için farkındalığı artırmaktadır. Daha önce bu bakış açısıyla kuramsal çerçeveler ele alınmış değildir. Bu anlamda alana yönelik katkının özgün bir katkı olduğu düşünülmektedir.

Mesleki müdahalelerde bireysel tasarruflar ile eklektik yaklaşım birbirine karıştırılmaktadır. $\mathrm{Bu}$ çalışmada savunulan eklektik yaklaşım, vakaların ve müracaatçıların öznelliğinin bir gereğidir ve uygulamadaki çeşitliliğin bilgi temelli yürütülmesinin bir karşılığıdır. Aksi takdirde kuramsal bilgi temelinden yoksun bir uygulama, bireysel tasarrufların önünü açabileceği gibi mesleki müdahalede sosyal çalışmacının rolünü de tartışılır hale getirecektir. $\mathrm{Bu}$ çalışmada savunulduğu şekliyle, kültürel farklılıklar görmezden gelinemez. 21. yy. dünyasında, uygulamaya dair çeşitliliğin bilimsel bir birliktelik içinde sunulabilmesinin önkoşulu kuramsal çeşitlilikle beslenen eklektik anlayıştır ki sosyal çalışmacıların mesleki rolünün ve müracaatçıların biricikliğinin gereğidir.

Çokkültürcü sosyal hizmet uygulamasını kültürel yetkinlik içinde sunulabilmek ve yürütebilmek adına sosyal çalışmacı adaylarının kültürel zekâ düzeylerinin ölçülerek ihtiyaç duyulan alt boyutlarda (üst biliş, biliş, motivasyon, davranış) desteklenmesi mesleği ve meslek elemanlarını daha etkili kılacaktır. Gerekirse bu konuda gerekli görülen saha ziyaretleri gerçekleştirilerek bilginin içselleştirilmesi ve hayata dönük dinamik bilgi birikimi sağlanmanın önü açılmalıdır. Aksi takdirde sosyal hizmet mesleği bilgi düzeyinde sıkıştırılmış, bilgi temelini hayata ve pratiğe yansıtamayan meslek olmaya itilmiş olacaktır. Meslek elamanları, müracaatçıların hayatlarına dokunamadıkları için değişim ve dönüşüm yapabilme gücünü ve inancını zaman içinde yitireceklerdir. Kültürel zekânın geliştirilebilir olması bu önerinin çıkış noktasını oluşturmaktadır.

Sosyal hizmetin uygulamalı bir bilim olarak teoriden ayrı düşünülmesi onu bilgi temelinden yoksun bir meslek haline dönüştürür. Yine birçok farklılık ve çeşitliliğin bir arada yaşandığı toplumlarda sosyal hizmet mesleğinin çokkültürcü uygulamaları müracaatçı kitlesi için görmezden gelinemeyecek bir gerçekliktir. Mesleğin uygulayıcısı olan sosyal çalışmacıların kuramsal bilgi temelinin çokkültürcü perspektiften eleştirel düşünce ile tekrar değerlendirilmesi, geliştirilmesi ve müracaatçının öznelliğini öne çıkaran eklektik yaklaşımların benimsenmesi uygulamada çoğulcu anlayışın güçlenmesine hizmet edecektir. 


\section{Kaynakça}

Acar, M. (2013). Onkolojide Sosyal Hizmet: Vaka Örnekleri. Toplum ve Sosyal Hizmet Dergisi. 24(2), 231-252.

Adams, R. (2015). Çocuklar, Gençler ve Ailelerle Çalışma. Adams, R., L. Dominelli ve M. Payne. (Der.). Sosyal Hizmet Temel Alanlar ve Eleştirel Tartışmalar içinde (33-41). (Çev.: Engin Fırat). Ankara: Nika Yayınevi.

Alğan, T.C. \& F.L. Şensever. (2010). Ulusal Basında Nefret Suçlart: 10 Yll, 10 Örnek. İstanbul: Sosyal Değişim Derneği.

Ang, S., L. Van Dyne, C. Koh, K.Y. Ng, K. J. Templar, C. Tay, \& N.A. Chandrasekar. (2007). Cultural Intelligence: Its Measurement and Effects On Cultural Judgment And Decision Making, Cultural Adaptation and Task Performance. Management and Organization Review, 3(03), 335-71.

Attepe Özden S. ve A. İçağasıŏlu Çoban. (2015). Sosyal Hizmet Eğitiminde Probleme Dayalı Öğrenme Yaklaşımının Kullanımı. Toplum ve Sosyal Hizmet Dergisi. 26(2), 159-168.

Bacanlı, H. (2014). Sosyal Beceri Eğitimi, 5. Baskı. İstanbul: Pegem Yayıncilık.

Baldwin, N. \& L. Walker. (2015). Değerlendirme. Adams, R., L. Dominelli ve M. Payne. (Der.). Sosyal Hizmet Temel Alanlar ve Eleştirel Tartışmalar içinde (255274). (Çev.: Buğra Yıldırım). Ankara: Nika Yay.

Cankurtaran, Ö. \& E. Beydilli. (2016). Ayrımcılık Karşıtı Sosyal Hizmet Uygulamasının Gerekliliği Üzerine. Toplum ve Sosyal Hizmet Dergisi. 27(1), 145-160.

Cree, V.E. (2015). Sosyal Hizmetin Değişen Yapısı. Adams, R., L. Dominelli ve M. Payne. (Der.). Sosyal Hizmet Temel Alanlar ve Eleştirel Tartışmalar içinde (5970). (Çev.: Çağıl Öngen). Ankara: Nika Yayınevi

Danış, Z. (2006). Davranış Bilimlerinde Ekolojik Sistem Yaklaşımı. Aile ve Toplum Dergisi. 3(9), 45-54.

Danış, Z. ve H. Z. Kara. (2016). Sosyal Hizmette Problem Çözme Yaklaşımı. The Journal of Academic Social Science Studies. Bahar (45), 1-10.

Demirtaş, H. A. (2003). Sosyal Kimlik Kuramı, Temel Kavramlar ve Varsayımlar. $A \ddot{U}$ İetişim: Araştırmaları Dergisi. 1(1), 123-144.

Earley, P. C. \& E. Mosakowski. (2004). Cultural Intelligence, Harvard Business Review, pp. 139-146.

Ercan F. Z. ve A. Tekgöz Obuz. (2016). Sosyal Hizmet Uygulamalarında Reflektif Düşüncenin Önemi. The Journal of Academic Social Science Studies. 49, 457465.

Eroğlu, H. T. (2013). Kamu Yönetiminde Sosyal Hizmetler. H. Acar, N. Cengiz ve E. Akman (Yayına Hazırlayanlar). Sosyal Politika ve Kamu Yönetimi Bileşenleriyle Sosyal Hizmet Temelleri ve Uygulama Alanları içinde (25-42). İstanbul: Maya Akademi Yay.
Glasser, W. (1999). Kişisel Özgürlüğün Psikolojisi Seçim Teorisi. İstanbul: Hayat Yay.

İlhan, M. \& B. Çetin. (2014). Kültürel Zekâ Ölçeği'nin Türkçe Formunun Geçerlik ve Güvenirlik Çalışması. Hacettepe Üniversitesi Ĕ̈itim Fakültesi Dergisi. 29(2), 94-114.

Keçeci, G. (2017). Makro Sosyal Hizmet Uygulanmasında Kullanılan Modeller, Teknikler ve Sosyal Hizmet Uzmanlarının Rolleri. Toplum ve Sosyal Hizmet Dergisi. 28(1), (187-202).

Kutlu, İ. \& F. Alsancak (2018). Çokkültürcülük Kimin Sorunudur? PESA Uluslararası Sosyal Araştırmalar Dergisi. 4(3), 295-303.

Mercan, N. (2016). Çok Kültürlü Ortamlarda Kültürel Zekânın Kültürler Arası Duyarlılık İle İlişskisine Yönelik Bir Araştırma. Niğde Üniversitesi İktisadi ve Idari Bilimler Fakültesi Dergisi. 9(1), 1-13.

Özbesler, C. \& I. Bulut (2013). Sosyal Hizmette Genelci Yaklaşım ve Ekolojik Perspektif. Acar, H., N. Cengiz ve E. Akman (Yayına Hazırlayanlar). Sosyal Politika ve Kamu Yönetimi Bileşenleriyle Sosyal Hizmet Temelleri ve Uygulama Alanlarl içinde (97-107). İstanbul: Maya Akademi Yay.

Özgür, Ö. (2010). Çokkültürcü Sosyal Hizmet: Eleştirel Bir Bakış. Toplum ve Sosyal Hizmet Dergisi. 21(2), 89104.

Öztürk, A.B. (2013). Kadına Yönelik Şiddetle Mücadelede Neredeyiz? Feminist Sosyal Çalışma Bağlamında Bir Değerlendirme. Acar, H., N. Cengiz ve E. Akman (Yayına Hazırlayanlar). Sosyal Politika ve Kamu Yönetimi Bileşenleriyle Sosyal Hizmet Temelleri ve Uygulama Alanları içinde (195-208). İstanbul: Maya Akademi Yay.

Payne, M. (2015). Sosyal Hizmet Sürecini Anlamak. Adams, R., L. Dominelli ve M. Payne. (Der.). Sosyal Hizmet Temel Alanlar ve Eleştirel Tartışmalar içinde (201217). (Çev.: Gökhan Topçu). Ankara: Nika Yay.

Sheafor, B.W. \& C.J. Horejsi. (2015). Sosyal Hizmet Uygulaması Temel Teknikler ve Illkeler, Çev. Ed. B. Çiftçi. 2. Baskı. Ankara: Nika Yay.

Şan, M.K. (2006). Farklılık ve Çokkültürlülük Siyasetleri Üstüne Bir Deneme. Milel ve Nihal Dergisi. 3(1-2), 69-117.

Teater, B. (2014). Sosyal Hizmet Kuram ve Yöntemler: Uygulama İçin Bir Giriş. (Çev. Ed.: Abdullah Karatay). Ankara: Nika Yay.

Thompson, N. (2016). Kuram ve Uygulamada Sosyal Hizmeti Anlamak 3. Bask1. Ankara: Dipnot Yay.

Tomanbay, İ. (1999). Sosyal Çalışmayı Yapılandırmak, Ankara: Sabev Yay.

Turan, N. (2012). Birey ve Aileler İle Sosyal Hizmet. Ankara: Sosyal Hizmet Uzmanları Derneği Yay.

Yaman, Ö.M. ve M.A. Akyurt. (2013). Sosyal Hizmete Kültürel Yaklaşım: 2011 Van Depremi Örneği. Sosyoloji Dergisi. 3(26), 105-144.

Yıldırım, N. \& K. Yıldırım. (2008). Sosyal Hizmet ve Yaklaşımlar. İstanbul: Sakarya Yay. 


\section{Extended Abstract}

\section{Introduction}

In applied professions such as social work, it is difficult to distinguish between practice and theory. Concept always affects action. Practice is basically "the process of using knowledge and applying theory to create a specific change" (Sheafor ve Horejsi, 2015: 68). According to Tomanbay (1999: 41), it is concept sensitivity that facilitates scientific perceptions and even creates a timbre.

Conceptual sensitivity in practice is to have a theoretical perspective. It is difficult for a social worker who does not have this perspective to be sensitive to practice, to use knowledge and to create change. Especially in societies with cultural diversity and differences, if structured theoretical frameworks and models are used instead of personal preferences for practice, it will be healthy for the integrity of practice. Otherwise, the integrity of the application cannot be guaranteed and the process carried out cannot be called scientific.

It would not be the right approach to expect all the answers needed from theoretical frameworks and theoretical approaches, but having a theoretical perspective is a required skill (Thompson, 2016: 99). In this context, knowing the theoretical frameworks that will guide the social worker and developing an eclectic approach from them is a requirement for multiculturalist social work in societies where there is cultural diversity.

\section{Aim and Importance}

In the study, theoretical frameworks that contribute to the social work profession were discussed from multiculturalist perspective and discussed in thematic titles created by the researchers. Thus, it was aimed to give the social worker an eclectic-based theoretical perspective in multiculturalist social work practices in societies where there is cultural diversity and differences. There is no previous study from this perspective. In addition, the thematic theoretical perspective is presented eclectically to social workers in the professional intervention process. This is significant in terms of social work literature.

\section{Method}

Literature review was used as a method in the study. The theoretical literature of social work was examined in this study. The theoretical frameworks included in the study are not explained one by one in order. It has been tried to give a theoretical perspective by classifying and discussing in accordance with the relevant themes.

Theoretical frameworks for practice are included in thematic titles as follows:

Table 1. Thematic Titles of the Theoretical Frameworks for Practice

\begin{tabular}{ll}
\hline Holistic View & Generalist Approach, System \\
& Theory, Empowerment Approach \\
Edaptation & Ecological System Approach, \\
& System Theory, Problem Solving \\
& Approach \\
& Psychodynamic Theory, \\
Therapeutic Relationship & Existentialist Theory, Strengths \\
& Perspective \\
& Ecological Perspective, Ethnic \\
Cultural Power & Sensitivity Model, Empowerment \\
& Approach, Problem Solving \\
& Approach \\
& Ethnic Sensitivity Model, Problem \\
Anti-Discrimination & Solving Approach, Feminist Theory, \\
& Radical Social Work \\
& Ethnic Sensitivity Model, Social \\
Cognitive Stinginess & Constructivist Model, Feminist \\
& Theory
\end{tabular}

Eclecticism

Source: Created by researchers.
The hypothesis of the research is as follows:

"Cultural differences cannot be ignored. In the 21st century world, the precondition for presenting practical diversity in a scientific unity is an eclectic understanding fed by theoretical diversity. This is due to the professional role of social workers and the uniqueness of the clients."

\section{Discussion and Conclusion}

The variety of theoretical frameworks to be used in the practice dimension in the social work discipline enriches the theoretical knowledge base of this discipline. It also serves to ensure unity, integrity and consistency in practice. The theoretical view which offers a perspective on practice in terms of concepts and principles is a professional skill that social workers need. These frameworks provide unity to social workers in practice and guide them in case management. However, it may not always be possible for social workers to use many theoretical frameworks in the literature on a case-by -case basis. Social workers' search for different techniques besides theoretical training in order to increase their practical skills is a reflection of this. (Ercan ve Tekgöz Obuz, 2016). For this reason, the theoretical frameworks were not discussed one by one in the study. Instead, theoretical frameworks in the context of multiculturalism were discussed under thematic headings. Discussing the theoretical frameworks under thematic titles contributes to the social worker in the multiculturalist social work practice and case management on the basis of knowledge. In addition, it is expected to prevent theoretical confusion in practice.

In multicultural societies, the fact that each of the clients come from different cultures and the same method can produce different results in solving the problems made it necessary to see the reflections of the cultural dimension in practice. Discussion of the theoretical framework of social work as an applied science in this context increases awareness for both applicants and social workers in order to give cultural sensitivity to the practice. Theoretical frameworks have not been discussed with this point of view before. In this sense, it is thought that the contribution of this study to the field is an original contribution.

In professional interventions, individual interventions and eclectic approach are confused. The eclectic approach advocated in this study is a requirement of the cases and the subjectivity of the clients. Otherwise, a practice lacking a theoretical knowledge base leads to individual approaches. It also makes the role of the social worker in professional intervention debatable. As argued in this paper, cultural differences cannot be ignored. In the 21 st century world, the precondition for presenting practical diversity in a scientific unity is an eclectic understanding fed by theoretical diversity. This is due to the professional role of social workers and the uniqueness of the clients.

Measuring the cultural intelligence levels of social worker candidates and supporting them in the required sub-dimensions (metacognition, cognition, motivation, behavior) will make the profession and professional staff more effective.. If necessary, field visits should be made on this subject and information should be internalized. This will pave the way for providing dynamic knowledge about life. Otherwise, the social work profession will be limited at the level of knowledge and pushed to be a profession that cannot reflect its knowledge base to life and practice. Moreover, professionals will lose their power and belief in making change and transformation over time because they cannot touch the lives of the clients. The fact that cultural intelligence can be improved is the starting point of this proposal.

Thinking of social work as an applied science separate from theory and neglecting the theoretical dimension turns it into a profession devoid of knowledge base. In societies where many differences and diversity exist together, the multiculturalist practices of the social work profession are a social reality that cannot be ignored for the client groups. Reevaluating and developing the theoretical knowledge base of social workers who are practitioners of the profession from a multiculturalist perspective and adopting eclectic approaches that emphasize the subjectivity of the client will serve to strengthen the pluralist understanding in practice. 